\title{
Randomized placebo-controlled trial of the effects of aspirin on dementia and cognitive decline
}

Joanne Ryan, PhD,* Elsdon Storey, MB, DPhil,* Anne M. Murray, MD, MSc, Robyn L. Woods, PhD, Rory Wolfe, PhD, Christopher M. Reid, PhD, Mark R. Nelson, MB, PhD, Trevor T.J. Chong, MBBS, PhD, Jeff D. Williamson, MD, MHS, Stephanie A. Ward, BMed, MPH, Jessica E. Lockery, MB, BS, Suzanne G. Orchard, PhD, Ruth Trevaks, PhD, Brenda Kirpach, CCRA, Anne B. Newman, MD, MPH, Michael E. Ernst, PharmD, John J. McNeil, MB, PhD, and Raj C. Shah, MD, on behalf of the ASPREE Investigator Group Neurology ${ }^{\circledR}$ 2020;95:e320-e331. doi:10.1212/WNL.0000000000009277

\section{Abstract \\ Objective \\ To determine the effect of low-dose aspirin vs placebo on incident all-cause dementia, incident Alzheimer disease (AD), mild cognitive impairment (MCI), and cognitive decline in older individuals.}

\section{Methods}

Aspirin in Reducing Events in the Elderly (ASPREE) was a double-blind, placebo-controlled trial of low-dose aspirin. In the United States and Australia, community-dwelling individuals aged $\geq 70$ years (US minorities $\geq 65$ years) and free of cardiovascular disease, physical disability, and diagnosed dementia were enrolled. Participants were randomized 1:1-100 mg daily aspirin or placebo. The Modified Mini-Mental State Examination, Hopkins Verbal Learning Test-Revised, Symbol Digit Modalities Test, and Controlled Oral Word Association Test assessed cognition at baseline and over follow-up. Additional cognitive testing was performed in participants with suspected dementia ("trigger") based on within-study assessments or clinical history. Dementia was adjudicated according to DSM-IV criteria. National Institute on Aging-Alzheimer's Association criteria were used for $\mathrm{AD}$ and $\mathrm{MCI}$ subclassification.

\section{Results}

A total of 19,114 participants were followed over a median 4.7 years and 964 triggered further dementia assessments. There were 575 adjudicated dementia cases, and $41 \%$ were classified as clinically probable AD. There was no substantial difference in the risk of all dementia triggers (hazard ratio [HR], 1.03; 95\% confidence interval [CI], 0.91-1.17), probable $\mathrm{AD}$ ( $\mathrm{HR}, 0.96$; 95\% CI, 0.74-1.24), or MCI (HR, 1.12; 95\% CI, 0.92-1.37) between aspirin and placebo. Cognitive change over time was similar in the aspirin and placebo groups.

\section{Conclusions}

There was no evidence that aspirin was effective in reducing risk of dementia, MCI, or cognitive decline. Follow-up of these outcomes after initial exposure is ongoing.

\section{Classification of evidence}

This study provides Class II evidence that for healthy older individuals, low-dose aspirin does not significantly reduce the incidence of dementia, probable $\mathrm{AD}, \mathrm{MCI}$, or cognitive decline.

\author{
Correspondence \\ Dr. Storey \\ elsdon.storey@monash.edu \\ or Dr. Ryan \\ joanne.ryan@monash.edu
}

\section{RELATED ARTICLE}

\section{Editorial}

The quest for dementia prevention does not include an aspirin a day

Page 105

\section{MORE ONLINE}

$\rightarrow$ Class of Evidence Criteria for rating therapeutic and diagnostic studies

NPub.org/coe

\section{Clinicaltrials.gov identifier NCT01038583.}

\footnotetext{
*These authors contributed equally to this work.
}

From the School of Public Health and Preventive Medicine (J.R., E.S., R.L.W., R.W., C.M.R., S.A.W., J.E.L., S.G.O., R.T., J.J.M.) and the Turner Institute for Brain and Mental Health (T.T.J.C.), Monash University, Melbourne, Australia; Berman Center for Outcomes and Clinical Research (A.M.M., B.K.), Hennepin Health Research Institute; Division of Geriatrics, Department of Medicine (A.M.M., B.K.), Hennepin Healthcare, Minneapolis, MN; School of Public Health (C.M.R.), Curtin University, Perth; Menzies Institute for Medical Research (M.R.N.), University of Tasmania, Hobart, Australia; Sticht Center on Aging and Alzheimer's Prevention, Section on Gerontology and Geriatric Medicine, Department of Internal Medicine (J.D.W.), Wake Forest School of Medicine, Winston-Salem, NC; Center for Aging and Population Health (A.B.N.), University of Pittsburgh, PA; Department of Pharmacy Practice and Science, College of Pharmacy, and the Department of Family Medicine, Carver College of Medicine (M.E.E.), University of lowa, lowa City; and Department of Family Medicine and Rush Alzheimer's Disease Center (R.C.S.), Rush University Medical Center, Chicago, IL.

Go to Neurology.org/N for full disclosures. Funding information and disclosures deemed relevant by the authors, if any, are provided at the end of the article.

Coinvestigators are listed in the appendix at the end of the article.

This Null Hypothesis article is published as part of a collaborative effort between Neurology® and CBMRT. 


\section{Glossary}

3MS = Modified Mini-Mental State Examination; AD = Alzheimer disease; ASPREE $=$ Aspirin in Reducing Events in the Elderly; CI = confidence interval; COWAT $=$ Controlled Oral Word Association Test; DSM-IV = Diagnostic and Statistical Manual of Mental Disorders, 4th edition; GP = general practitioner; HR = hazard ratio; HVLT-R = Hopkins Verbal Learning Test-Revised; $\mathbf{M C I}=$ mild cognitive impairment; NIA = National Institute on Aging; NSAID = nonsteroidal anti-inflammatory drug; SDMT = Symbol Digit Modalities Test.

Low-dose aspirin is one of the most widely used treatments for the secondary prevention of cardiovascular disease. ${ }^{1}$ As an anti-inflammatory and antiplatelet agent, aspirin also has the potential to prevent or delay the onset of dementia. Inflammation is one of the driving forces in Alzheimer disease (AD) pathology $y^{2}$ and aspirin may also act through a reduction in amyloid pathology. ${ }^{3}$ A reduction in cerebrovascular disease, including strokes, with aspirin treatment may also help prevent vascular dementia. ${ }^{4}$

Observational data have suggested that nonsteroidal antiinflammatory drugs (NSAIDs), including aspirin, may be neuroprotective, reducing cognitive decline and incident dementia. ${ }^{5}$ However, there has been a dearth of large highquality randomized controlled trials of NSAIDs, particularly those investigating the effects of low-dose aspirin. ${ }^{6}$

The Aspirin in Reducing Events in the Elderly (ASPREE) trial was a randomized placebo-controlled trial of low-dose aspirin in healthy older individuals. We previously reported that aspirin did not prolong disability-free survival, nor did it decrease the risk of incident dementia, a component of the disability-free survival composite endpoint. ${ }^{7}$ However, as dementia is a clinical syndrome with heterogeneous pathologic causes, the focus on all-cause dementia may dilute out an effect on $\mathrm{AD}$ specifically. Furthermore, given the long prodromal stage in $\mathrm{AD}$, an effect earlier in the trajectory of cognitive decline may have been overlooked. Here we describe the effect of aspirin on the prespecified secondary outcomes, incident clinically probable and possible $\mathrm{AD}$ and mild cognitive impairment (MCI), as well as on the rate of cognitive decline.

\section{Methods}

\section{Study design}

Full details regarding the rationale and study design, including detailed inclusion and exclusion criteria, have been reported previously. ${ }^{7,8}$ In brief, between March 2010 and December 2014, initially healthy community-dwelling individuals aged 70 years and over were identified through partnership with $>2,000$ general practitioners (GPs) in Australia and in the United States through clinic-based mailing lists, electronic medical screening, and media advertisements. ${ }^{9}$ For African American and Hispanic patients in the United States, the age limit was lowered to 65 years and over due to their higher risk of disease. Individuals were then sent a letter inviting them to participate in eligibility screening. Eligibility criteria included being free from cardiovascular disease and physical disability and being expected to survive for at least 5 years. Individuals with a self-report or physician diagnosis of dementia at recruitment, or with a Modified Mini-Mental State Examination $(3 \mathrm{MS})^{10}$ score of less than 78 , were also ineligible. There were no other inclusion/exclusion criteria for cognitive function, meaning it was possible that some individuals had prevalent MCI.

The double-blind treatment phase of the trial, initially scheduled to run for 5 years, was stopped 6 months early by the sponsor on June 12, 2017, because of futility for the primary composite outcome of disability-free survival (survival free from persistent physical disability, dementia, or death).

\section{Randomization and treatment allocation}

Eligible participants were enrolled in a 4-week run-in phase, where adherence was monitored to placebo tablets, the identity of which was not disclosed to the participant. Participants with $80 \%$ or higher compliance were then randomized 1:1 to receive daily either $100 \mathrm{mg}$ enteric coated aspirin (Bayer Pharma AG, Leverkusen, Germany) or an identicalappearing placebo tablet. Block randomization with a computer-generated randomization procedure in Stata Statistical software (StataCorp, College Station, TX) was used and was stratified according to location of general practice in Australia, regional site in the United States, and age (65-79 or $\geq 80$ years) to ensure balanced allocation across groups. Participants, study investigators, and GPs were all blinded to treatment assignment for the entire period of the trial.

Data were gathered through quarterly contact with participants by telephone and by annual in-person clinical assessments. Monitoring of safety was conducted as described previously, ${ }^{7}$ with the trial sponsor (the National Institute on Aging [NIA]) and an independent data and safety monitoring board reviewing the reports on the accumulating data at regular intervals. Site monitoring reports were reviewed by an international data management committee to monitor information about adherence to the protocol and data quality.

\section{Standard protocol approvals, registrations, and patient consents}

The study protocol was approved by institutional review boards in both countries and the NIH. All participants provided written informed consent. The study is registered at Clinicaltrials.gov (NCT01038583). 


\section{Outcome measures}

Cognitive assessments were administered by trained and accredited staff at baseline and year 1 , and then biennially over the follow-up period (year 3, year 5, and year 7 or close-out visit in 2017). The cognitive battery included the $3 \mathrm{MS}$ to measure global cognition, ${ }^{11}$ the Hopkins Verbal Learning Test-Revised (HVLT-R) ${ }^{12}$ Delayed Recall task for episodic memory, the single letter (F) Controlled Oral Word Association Test $(\mathrm{COWAT})^{13}$ for language and executive function, and the Symbol Digit Modalities Test $(\mathrm{SDMT})^{14}$ to measure psychomotor speed.

\section{Incident dementia}

Individuals with a suspected dementia diagnosis ("trigger") were referred for further standardized cognitive and functional assessments. Dementia triggers were defined as a $3 \mathrm{MS}$ score $<78,{ }^{15}$ a drop of more than 10.15 points from the predicted score based on their own baseline 3MS and after adjustment for age and education, ${ }^{16}$ a report of memory concerns or other cognitive problems to a specialist, or, as noted on the participant's medical records, a clinician diagnosis of dementia or prescription of cholinesterase inhibitors (this latter criteria was an automatic trigger in Australia as an $\mathrm{AD}$ diagnosis by a medical specialist was a requirement for a Pharmaceutical Benefits Scheme subsidized prescription; in the United States, these were reviewed by the local sites to determine if the prescription was for a cognitive indication). Additional evaluations were administered at least 6 weeks after the initial dementia trigger to reduce the possibility of delirium. These included the Alzheimer's Disease Assessment Scale-Cognitive subscale, ${ }^{17}$ Color Trails, ${ }^{18}$ Lurian overlapping figures, ${ }^{19}$ and the Alzheimer Disease Cooperative Study Activities of Daily Living scale, completed by the participant and, if available, study partner. ${ }^{20}$ Other documentation relevant to the dementia assessment including laboratory tests, brain CT or MRI, the results of blood tests, and clinical case notes were also sought from clinical providers and hospitals, along with initial impression for cognitive change from the evaluating clinician.

The available information was reviewed by the dementia adjudication committee, a panel of neurologists, neuropsychologists, and geriatricians from Australia and the United States with expertise in dementia who were blinded to treatment allocation. Dementia was adjudicated according to DSMIV criteria. $^{21}$ This required evidence of memory impairment plus evidence of at least one of the following: aphasia, apraxia, agnosia, or executive dysfunction. The cognitive impairments needed to have caused significant impairment in social or occupational functioning and to have represented a significant decline from a previous level of functioning. The date of diagnosis of dementia was taken as the date the dementia trigger occurred that resulted in a confirmed dementia diagnosis by the adjudication committee.

\section{Subclassification of dementia}

With supplementary funding in 2012, subclassification of all dementia cases into clinically probable and possible $\mathrm{AD}$ was performed according to the 2011 NIA-Alzheimer's Association core clinical criteria. ${ }^{22}$ This includes insidious onset, worsening over time, and amnestic or nonamnestic presentation. Possible $\mathrm{AD}$ was classified as individuals who meet the core $\mathrm{AD}$ criteria but with an atypical course or etiologic mixed presentation, including those with neuroimaging consistent with moderate or marked cerebrovascular pathology, including white matter ischemia.

\section{Mild cognitive impairment}

MCI was defined as participants with a dementia trigger who were subsequently adjudicated as not reaching the dementia endpoint by the dementia adjudication committee. Subclassification as $\mathrm{MCI}$ probably due to $\mathrm{AD}$ or "other" (including participants with evidence of functional decline or $\mathrm{MCI}$ not consistent with $\mathrm{AD}$ or insufficient information to determine) was made using standard criteria. ${ }^{23}$

\section{Cognitive decline and change}

In participants without a dementia trigger, we also defined those with significant cognitive decline as a $>1.5$ SD decline in cognitive score from their own baseline value on the HVLT-R Delayed Recall, SDMT, or COWAT. This definition did not include participants with evidence of only a transient decline (e.g., those with a $>1.5$ SD drop at 1 follow-up, but scoring above this threshold at a subsequent follow-up).

Cognitive change was examined using the continuous scores on each of the cognitive tests over the follow-up period.

\section{Subgroups}

Prespecified subgroup analyses in the trial protocol included sex (male vs female), age (below or median and above), country of recruitment (United States vs Australia), ethnicity/ race (white vs African American vs Hispanic/Latino vs other), diabetes (no vs yes), hypertension (no vs yes), dyslipidemia (no vs yes), smoking (current vs former vs never), previous regular aspirin use (no vs yes), body mass index, and frailty using adapted Fried frailty criteria (not frail vs prefrail vs frail). ${ }^{24}$

\section{Statistical analysis}

All analyses were restricted to events that occurred on or prior to June 12, 2017, during the intervention phase of the trial, and compared aspirin and placebo groups using an intention-to-treat approach. For the time-to-event analysis, the difference between the date at randomization to study medication and the event was calculated. The sample size of 19,000 was based on the primary outcome, disability-free survival, with $90 \%$ power to detect a hazard ratio of 1.23 comparing the aspirin and placebo groups.

Cox proportional hazards regression models with time-toevent analysis were used to compare the aspirin and placebo groups. Hazard ratios (HRs) were calculated for dementia triggers and all-cause dementia. A cumulative incidence function was used to display the risk of dementia triggers or allcause dementia based on a competing risks regression model stratified by treatment group and allowing for the competing 
risk of death. ${ }^{25}$ Proportional hazards assumptions were tested as a null hypothesis of zero slope in a regression of scaled Schoenfeld residuals against time; all $p$ values were found to be $>0.1$, indicating satisfaction of the assumption for all outcomes.

Subgroup analysis was used to investigate the effect of aspirin vs placebo across prespecified subgroups. ${ }^{24}$ An interaction term in the Cox proportional hazards models provided an estimate of the effect heterogeneity between subgroups.

Similar analyses were undertaken to investigate probable and possible $\mathrm{AD}, \mathrm{MCI}$, and cognitive decline.

Linear mixed models were used to compare change in cognitive function over time in the participants randomized to aspirin vs placebo. All randomized participants were included and contributed data to the estimation of intercepts at baseline and at follow-ups when available. Given the small number of participants who had cognitive assessment at the year 2 and year 7 follow-ups ( $<100$ participants), the cognitive scores from these timepoints were not included in the analysis. Each of the 4 cognitive tests (3MS, HVLT-R Delayed Recall, SDMT, and COWAT) was investigated individually, and we also analyzed a global composite measure derived using a summed $z$ score (average of the 4 tests). Composite scores are commonly used in cognitive research, as they have less variability than individual neuropsychological test scores, and can reduce floor and ceiling effects. ${ }^{26}$ Each model included treatment group (aspirin vs placebo), annual visit/time (0 [baseline], 1, 3, 4, 5, 6), a participantspecific intercept (baseline score), and a participant-specific slope describing change in score over time (per annual visit). To examine whether the trajectory of cognitive scores for an average participant differed between treatment groups, a treatment by time interaction was included in the model. Analyses were performed using Stata software, release 15 (StataCorp).

\section{Classification of evidence}

This prospective, randomized, double-blind, placebocontrolled clinical trial (ASPREE) assessed the effect of treatment with $100 \mathrm{mg}$ once daily enteric-coated aspirin vs placebo over 5 years on the prespecified secondary outcomes incident dementia and MCI overall, and in prespecified subgroups. An ancillary study (supplement awarded in 2012) to ASPREE had a prespecified primary aim to examine the effect of daily low-dose aspirin on $\mathrm{AD}$. This study provides Class II evidence that aspirin does not affect the incidence of probable $\mathrm{AD}, \mathrm{MCI}$, or cognitive decline over a median 4.7 years, in individuals aged $\geq 65$ years without dementia at baseline.

Figure 1 Consolidated Standards of Reporting Trials (CONSORT) flow diagram of participants in the Aspirin in Reducing Events in the Elderly (ASPREE) trial

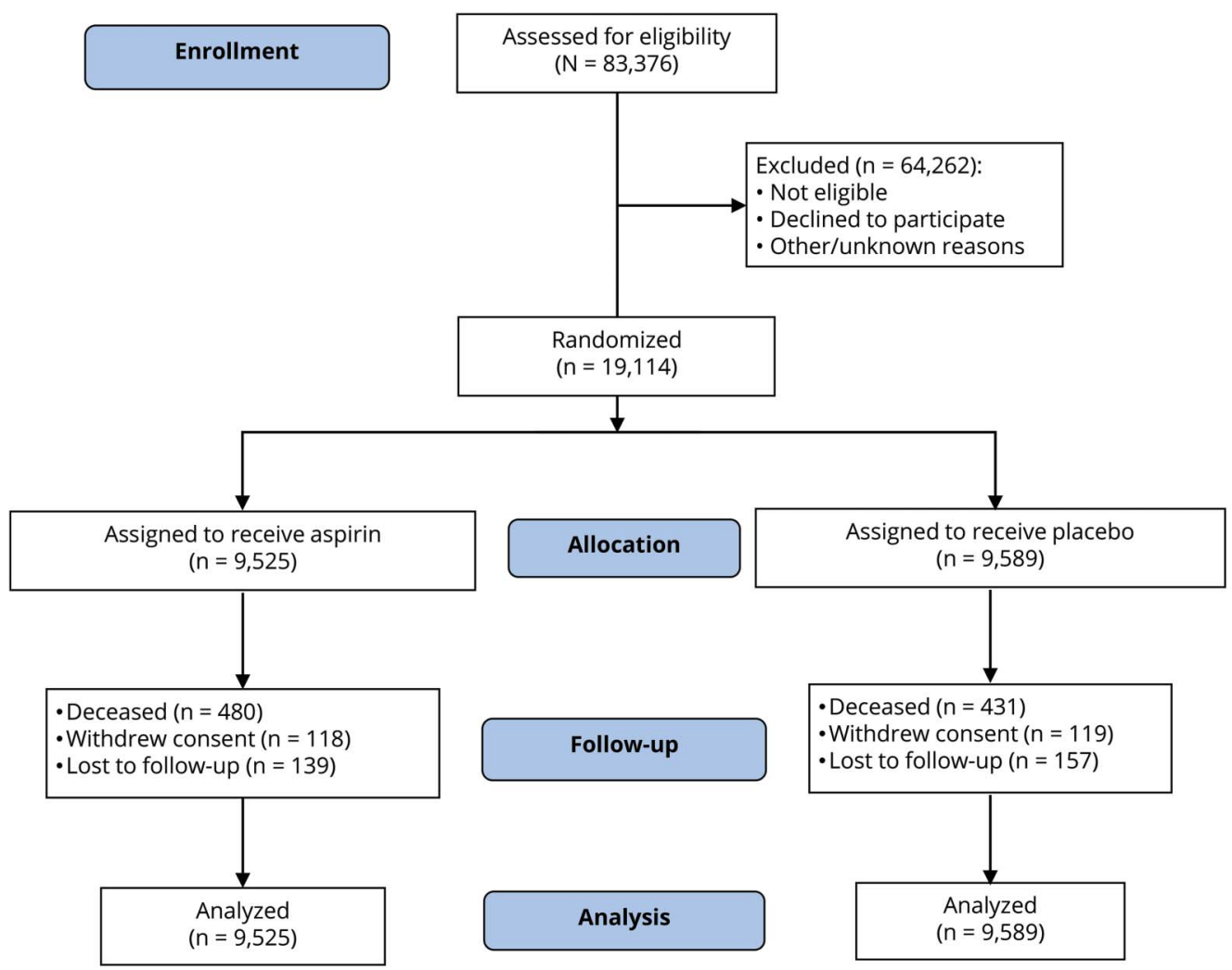

All randomized participants were included in the final analysis. For participants who withdrew from the trial or died, all information up to the point of withdrawal/death was included in the analysis. 


\section{Data availability}

All individual participant data (re-identifiable) that underlie the results reported in this article are available upon request to qualified researchers without limit of time, subject to approval of the analyses by the principal investigators and a standard data sharing agreement. Details regarding requests to access the data will be available through the study web site (ASPREE.org). The data will then be made available through a web-based data portal safe haven at Monash University, Australia. The ASPREE trial protocol and statistical analysis plan have been published. ${ }^{7}$

\section{Results}

\section{Study participants}

A total of 19,114 participants were recruited, with 9,525 randomized to aspirin and 9,589 to placebo (figure 1). Participants ranged in age from 65 to 98 years, and $87.4 \%$ were recruited in Australia. No significant differences were identified in baseline characteristics between participants randomized to aspirin and placebo, including health factors and cognitive performance that may predispose to cognitive impairment (table 1).

The median duration of follow-up was the same in the 2 groups (4.7 years; interquartile range, 3.6-5.7 years). At the end of the follow-up period, face-to-face visits were still being conducted on $82 \%$ of participants, $9.7 \%$ via review of medical records only, and $5.5 \%$ had died (11). Loss to follow-up was defined as no contact with participants, either in person or by phone, in the 12 months before the end of the trial period (June 12, 2017), and no record of the participant having attended the medical practice within the last 12 months. Only $1.2 \%$ of participants withdrew consent for any follow-up, and this was balanced across the 2 study groups (figure 1). As reported previously, aspirin did not prolong disability-free survival (HR, 1.01; 95\% confidence interval $[\mathrm{CI}], 0.92-1.11)^{7}$

\section{Incident dementia and probable AD}

In the aspirin group, 488 participants (11.6 per 1,000 person-years) reached the dementia trigger criteria compared with 476 participants (11.3 per 1,000 person-years) in the placebo group (HR, 1.03; 95\% CI, 0.91-1.17). The type of dementia trigger was similar across the aspirin and placebo groups, with similar rates of reported memory problems (4.4 and 4.6 per 1,000 person-years, respectively), 3MS score $<78$ (4.1 and 4.3 per 1,000 person-years, respectively), $>10$-point drop in predicted 3MS from baseline (1.5 and 1.7 per 1,000 person-years, respectively), and prescribed a cholinesterase inhibitor (1.0 and 0.7 per 1,000 person-years, respectively).

The rate of incident dementia in the aspirin group was 6.7 events per 1,000 person-years and in the placebo group 6.9 events per 1,000 person-years (table 2). Fewer than half of all adjudicated dementia cases (41\%) were classified as clinically probable $\mathrm{AD}$.

The 95\% CI for HR indicating the difference in the risk of incident clinically probable $\mathrm{AD}$ and possible $\mathrm{AD}$ in the aspirin and placebo groups overlaps 1.0 (figure 2).
Table 1 Selected participant characteristics at randomization according to treatment group ${ }^{a}$

\begin{tabular}{lll}
\hline & $\begin{array}{l}\text { Aspirin } \\
(\mathbf{n}=\mathbf{9 , 5 2 5})\end{array}$ & $\begin{array}{l}\text { Placebo } \\
(\mathbf{n}=\mathbf{9 , 5 8 9})\end{array}$ \\
\hline Ethno-racial group, $\mathbf{n}(\%)$ & & \\
\hline Australian white & $8,169(85.8)$ & $8,193(85.4)$ \\
\hline US white & $539(5.7)$ & $549(5.7)$ \\
\hline African American & $451(4.7)$ & $450(4.7)$ \\
\hline Hispanic/Latino & $240(2.5)$ & $248(2.6)$ \\
\hline Other & $126(1.3)$ & $149(1.6)$ \\
\hline Age, $\mathbf{y}, \mathbf{n}$ (\%) & & \\
\hline $\mathbf{6 5 - 6 9}$ & $284(3.0)$ & $280(2.9)$ \\
\hline $\mathbf{6 5 - 7 4}$ & $5,243(55.0)$ & $5,356(55.9)$ \\
\hline $\mathbf{7 5 - 8 4}$ & $3,618(38.0)$ & $3,601(37.6)$ \\
\hline $\mathbf{8 8 5}$ & $380(4.0)$ & $352(3.7)$
\end{tabular}

Education, y, $\mathrm{n}(\%)$

\begin{tabular}{|c|c|c|}
\hline$<12$ & $4,307(45.2)$ & $4,329(45.2)$ \\
\hline $12-15$ & $2,802(29.4)$ & $2,772(28.9)$ \\
\hline $16+$ & $2,415(25.4)$ & $2,488(26.0)$ \\
\hline Male, n (\%) & $4,152(43.6)$ & $4,180(43.6)$ \\
\hline Drinks alcohol, n (\%) & $7,309(76.7)$ & $7,333(76.5)$ \\
\hline Current or past smoker, $\mathbf{n}(\%)$ & $4,261(44.7)$ & $4,273(44.6)$ \\
\hline Obese, $\geq 30 \mathrm{~kg} / \mathrm{m}^{2}, \mathrm{n}(\%)$ & $2,820(29.7)$ & $2,857(29.9)$ \\
\hline Depression, $n(\%)^{c}$ & $925(9.7)$ & $954(10.0)$ \\
\hline 3MS, mean (SD) & $93.4(4.7)$ & $93.5(4.6)$ \\
\hline COWAT, mean (SD) & $12.1(4.6)$ & $12.1(4.6)$ \\
\hline SDMT, mean (SD) & $36.7(10.1)$ & $36.8(10.2)$ \\
\hline
\end{tabular}

HVLT-R, mean (SD)

\begin{tabular}{lll}
\hline Total recall & $22.5(5.5)$ & $22.5(5.5)$ \\
\hline Delayed Recall & $7.7(2.8)$ & $7.7(2.8)$ \\
\hline \% Retention & $83.2(22.2)$ & $83.3(22.1)$ \\
\hline RDI & $10.7(1.7)$ & $10.7(1.8)$ \\
\hline
\end{tabular}

Abbreviations: $3 \mathrm{MS}=$ Modified Mini-Mental State Examination; COWAT = Controlled Oral Word Association Test; HVLT-R = Hopkins Verbal Learning Test-Revised; RDI = Recognition Discrimination Index; SDMT = Symbol Digit Modalities Test.

a Prior published data indicate no difference by trial group for a range of other health conditions, including diabetes, hypertension, and body mass index. ${ }^{7}$ ${ }^{\mathrm{b}}$ All US ethnic minorities.

' Depression was defined as a score of $\geq 8$ on the 10-item Center for Epidemiologic Studies Depression Scale (CES-D-10).

There were no significant interactions between treatment group and any prespecified subgroup for dementia (figure 3) or probable $\mathrm{AD}$ (data not shown), with the exception of frailty, but in this latter case, the direction of effect was inconsistent across frailty categories. 
Table 2 The effect of aspirin vs placebo on incident dementia, Alzheimer disease (AD), and mild cognitive impairment $(\mathrm{MCl})$

\begin{tabular}{|c|c|c|c|c|c|}
\hline & \multicolumn{2}{|l|}{ Aspirin $(n=9,525)$} & \multicolumn{2}{|l|}{ Placebo $(n=9,589)$} & \multirow[b]{2}{*}{$\begin{array}{l}\text { Hazard ratio } \\
(95 \% \mathrm{Cl})\end{array}$} \\
\hline & $\begin{array}{l}\text { No. of participants } \\
\text { with event }\end{array}$ & $\begin{array}{l}\text { Rate per } 1,000 \\
\text { person-years }\end{array}$ & $\begin{array}{l}\text { No. of participants } \\
\text { with event }\end{array}$ & $\begin{array}{l}\text { Rate per } 1,000 \\
\text { person-years }\end{array}$ & \\
\hline Dementia diagnosis & 283 & 6.7 & 292 & 6.9 & $0.98(0.83-1.15)$ \\
\hline Clinically probable AD & 116 & 2.8 & 122 & 2.9 & $0.96(0.74-1.24)$ \\
\hline Clinically possible AD & 166 & 3.9 & 163 & 3.8 & $1.03(0.83-1.27)$ \\
\hline Likely non-AD & 1 & 0.02 & 6 & 0.14 & $0.17(0.02-1.39)$ \\
\hline $\mathrm{MCl}$ & 205 & 4.9 & 184 & 4.4 & $1.12(0.92-1.37)$ \\
\hline $\mathrm{MCl}$ consistent with $\mathrm{AD}$ & 47 & 1.1 & 38 & 0.9 & $1.13(0.81-1.91)$ \\
\hline $\mathrm{MCl}$ other ${ }^{\mathrm{a}}$ & 158 & 3.8 & 146 & 3.5 & $1.10(0.87-1.37)$ \\
\hline Cognitive decline & 838 & 26.5 & 816 & 25.6 & $1.04(0.94-1.14)$ \\
\hline
\end{tabular}

Abbreviation: $\mathrm{Cl}=$ confidence interval.

a Includes participants with evidence of functional decline or $\mathrm{MCl}$ not consistent with AD or insufficient information to determine.

\section{$\mathrm{MCl}$ and cognitive decline}

Overall there were 389 participants with incident MCI, with $22 \%$ classified as MCI due to $\mathrm{AD}$. The rates were similar between the aspirin and placebo groups (figure 4).

In the aspirin group, 838 participants (26.5 per 1,000 personyears) were defined as having cognitive decline, compared with 816 participants (25.6 per 1,000 person-years) in the placebo group (HR, 1.04; 95\% CI, 0.94-1.14).

\section{Cognitive change}

Cognitive performance over follow-up in the aspirin and placebo groups is shown in table 3 . There were small changes in cognitive function over time but there was no evidence that the average trajectory differed between aspirin and placebo groups.
These findings remained essentially unchanged in sensitivity analysis excluding individuals who had died or reached the dementia endpoint, or to help account for possible practice effects by removing baseline performance from the analysis.

\section{Discussion}

We previously reported in ASPREE that daily low-dose aspirin initiated in older adults did not prolong disability-free survival but increased the risk of major hemorrhage, compared with placebo. ${ }^{7}$ Low-dose aspirin exposure had no overall effect on all-cause dementia incidence.

In this study, we extend our initial findings to include prespecified subgroup analysis and assessment of secondary cognitive

Figure 2 Cumulative incidence of dementia subtype

A. Probable AD

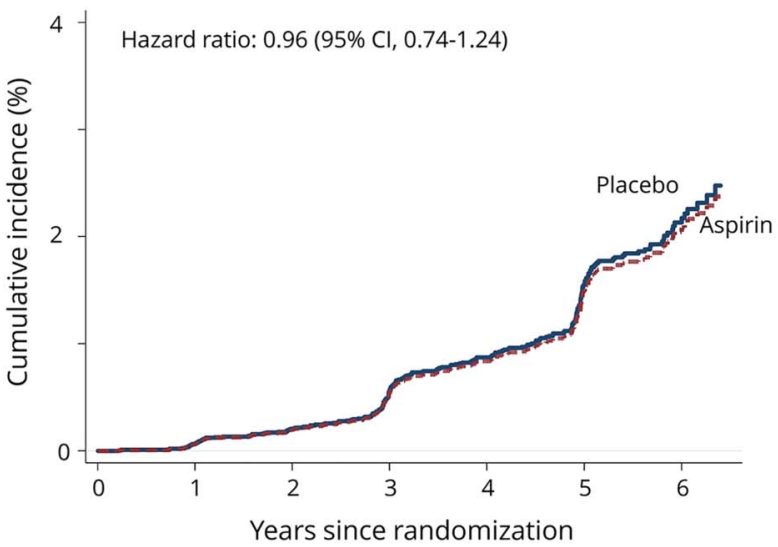

\section{B. Possible AD}

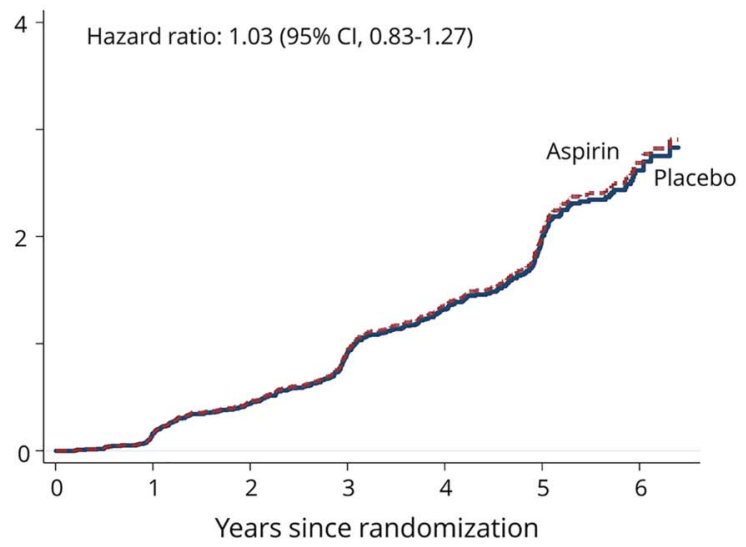

Cumulative incidences of all events of clinically probable Alzheimer disease (AD) and possible AD that were observed during the trial. $\mathrm{Cl}=$ confidence interval. 
Figure 3 Forest plot for adjudicated incidence of dementia (all-cause) in prespecified subgroups

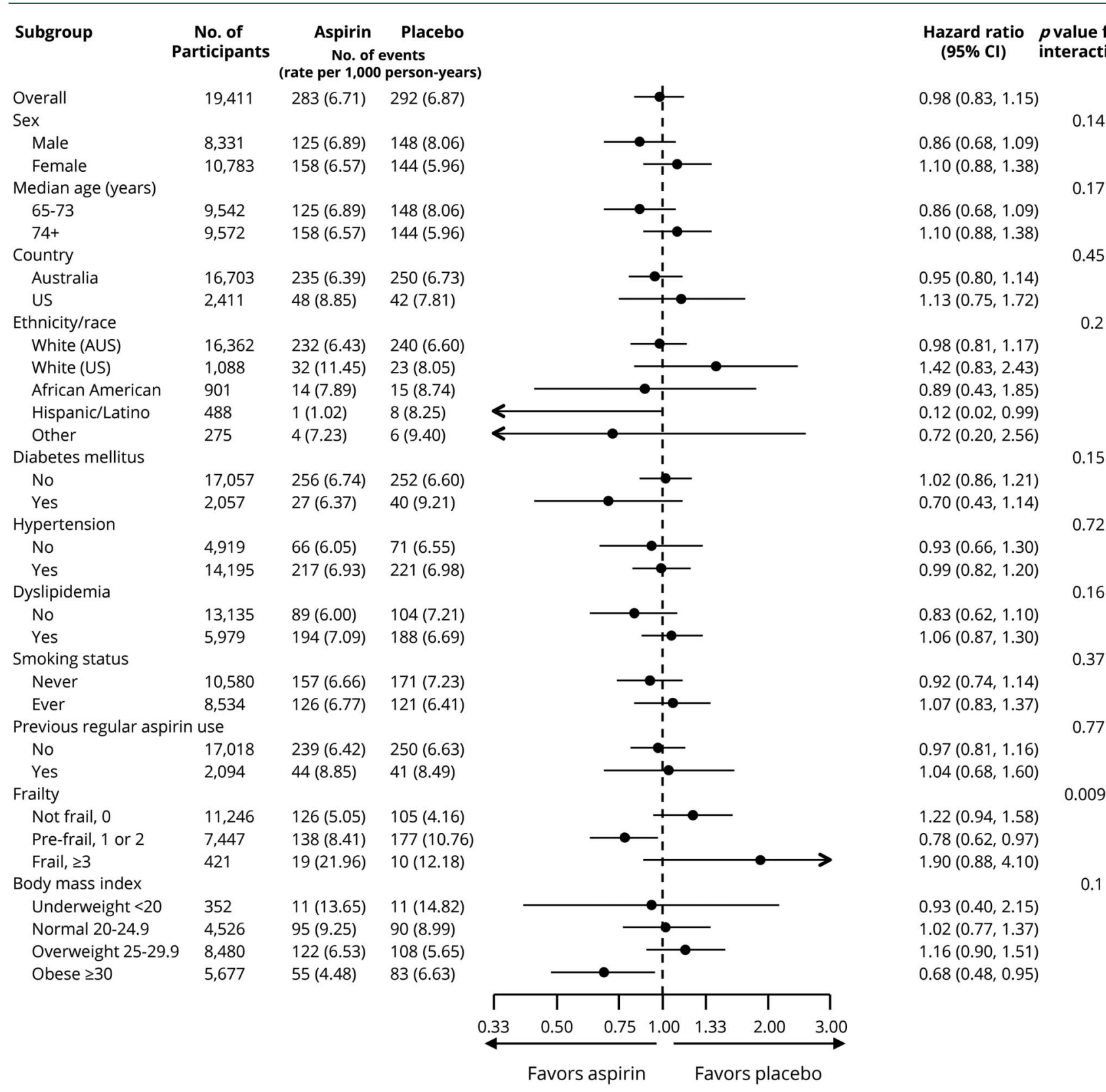

Arrows indicate that the $95 \%$ confidence intervals (CIs) were beyond the scale. Other ethnic/racial group included individuals who were not Hispanic but who did not state another race or ethnic group (18), or any other category with fewer than 200 participants overall. This included Aboriginal or Torres Strait Islander (12 participants), Native American (6), multiple races or ethnic groups (64), and Native Hawaiian or Pacific Islander (11). The presence of diabetes was based on participants' report of diabetes mellitus or a fasting glucose level of at least $126 \mathrm{mg} / \mathrm{dL}$ ( $\geq 7 \mathrm{mmol} / \mathrm{L}$ ) or receipt of treatment for diabetes. Hypertension was defined as treatment for high blood pressure or a blood pressure of greater than $140 / 90 \mathrm{~mm} \mathrm{Hg}$ at trial entry. Dyslipidemia was defined as the receipt of cholesterol-lowering medication or as a serum cholesterol level of at least $212 \mathrm{mg} / \mathrm{dL}(\geq 5.5 \mathrm{mmol} / \mathrm{L}$ ) in Australia and at least $240 \mathrm{mg} / \mathrm{dL}$ ( $\geq 6.2 \mathrm{mmol} / \mathrm{L}$ ) in the United States or as a low-density lipoprotein level of more than $160 \mathrm{mg} / \mathrm{dL}$ ( $>4.1 \mathrm{mmol} / \mathrm{L})$. Previous regular aspirin use was defined according to participantreported regular use of aspirin immediately before the first baseline visit, with a 1-month washout period before randomization. Frailty was categorized on the basis of the adapted Fried frailty criteria, which included body weight, strength, exhaustion, walking speed, and physical activity. The category of prefrail included participants who met 1 or 2 criteria, and the category of frail included those who met 3 or more criteria. Body mass index is the weight in kilograms divided by the square of the height in meters.

outcomes. We report a consistent lack of benefit of aspirin on rates of clinically probable and possible $\mathrm{AD}, \mathrm{MCI}$, and cognitive decline, which were approximately equal between the treatment groups. There was no effect of aspirin vs placebo on global cognition or specific cognitive domains (i.e., memory, psychomotor speed, language, and executive function). Furthermore, treatment effects did not vary across subgroups, including those defined by age, sex, ethno-racial group, health factors, or prior NSAID use.

Given the rigor of this large double-blinded placebocontrolled trial and the consideration of potential effects of aspirin on early and more severe stages of cognitive impairment, this study provides strong evidence that in older 

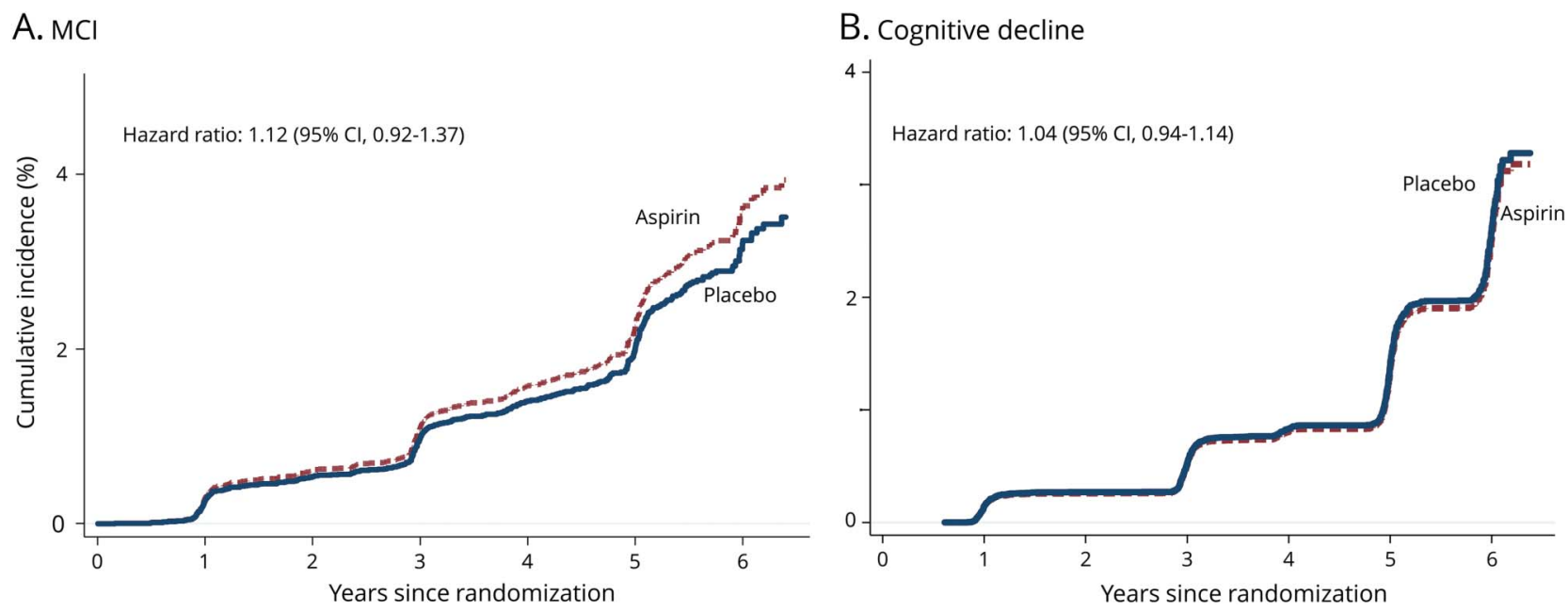

Cumulative incidences of all events of incident $\mathrm{MCl}$ and cognitive decline that were observed during the trial. $\mathrm{Cl}=$ confidence interval.

individuals, initiation of low-dose aspirin and continuation over a median 4.7 years is not effective in reducing the risk of cognitive decline, dementia, or $\mathrm{AD}$.

The pharmacologic properties of aspirin have raised the possibility of a preventive effect in reducing cognitive decline and the incidence of both $\mathrm{AD}$ and vascular dementia. It has been hypothesized that aspirin's potential beneficial effect could be via the suppression of inflammation ${ }^{2}$ or prevention of ischemic damage and a reduction in cerebrovascular disease. ${ }^{4}$ On the other hand, aspirin could potentially increase the risk of cerebral microbleeds, ${ }^{27}$ which have been associated with cognitive impairment. ${ }^{28}$ A recent meta-analysis of observational data from 16 cohorts involving 236,022 participants found that ever use of NSAIDs was associated with a reduced risk of $\mathrm{AD} .^{29}$ However, interpretation of significant findings from observational studies can be difficult as prescription and health user bias, as well as residual confounding, may account for reported associations. ${ }^{30}$

Two previous trials of low-dose aspirin have been reported, but neither has specifically investigated the effect on all-cause dementia or $\mathrm{AD}$. A study involving a subsample of 6,377 women aged 65 years from the Women's Health Study found that lowdose aspirin ( $100 \mathrm{mg}$ on alternate days) for a mean of 9.6 years was not associated with overall change in global cognition or cognitive decline, although they did find some evidence for reduced decline in category (semantic) fluency. ${ }^{31}$ The other large trial (The Aspirin for Asymptomatic Atherosclerosis Trial) of aspirin (100 mg daily) in 3,350 men and women over 50 years and at moderately increased risk of cardiovascular disease also failed to show any benefit in preserving cognitive function. ${ }^{32}$

Although NSAIDs are structurally diverse and aspirin differs in pharmacokinetic and pharmacodynamic properties from other NSAIDs, ${ }^{33}$ the results of our study are in keeping with trials of other NSAIDs. The Alzheimer's Disease Anti-Inflammatory Prevention Trial (ADAPT) investigated the effect of a median 1.5 years of naproxen or celecoxib treatment in 2,528 individuals aged 70 years and over at high risk of $\mathrm{AD} .{ }^{34}$ Cognitive decline and incident $\mathrm{AD}$ were assessed over a 7-year follow-up. The trial found no evidence for efficacy. ${ }^{34}$ The smaller Investigation of Naproxen Treatment Effects in Pre-symptomatic Alzheimer's Disease (INTREPAD) trial also examined the effect of daily naproxen over 2 years in 195 asymptomatic individuals with a strong family history of $\mathrm{AD}$ aged 60 years and over. ${ }^{35}$ They found no beneficial effect on cognition or a composite measure of cognition, imaging, and blood biomarkers.

The ASPREE sample was community-based, meaning that it is generalizable to individuals in the primary care setting. However, there are limitations to the study that need to be considered when interpreting the null results. First, the reduced incidence of dementia and MCI compared with the rates reported in previous studies ${ }^{36,37}$ may have reduced the likelihood of detecting efficacy. This lower incidence is likely explained by the inclusion of participants who were relatively healthy at baseline, without established cardiovascular disease or other major illnesses and with a 3MS score above 77. Of note, however, vascular risk factors were not uncommon among participants in the trial, with, for example, $11 \%$ having diabetes mellitus and $74 \%$ hypertension at baseline. ${ }^{7}$ Another possible explanation for the low incidence of $\mathrm{MCI}$ is likely to be the stringent criteria that were applied in this study, which may not have identified all cases of incident MCI. However, our definition of cognitive decline ( $>1.5 \mathrm{SD}$ drop on at least one cognitive test) in individuals without dementia likely captures a broader MCI definition, with a $>5$-fold higher incidence, and the findings were consistent. A second possible limitation is that the low dose of aspirin employed may have been insufficient to suppress inflammation, although its antiplatelet effects could still benefit cognition. ${ }^{33}$ Third, it is plausible that 
Table 3 Cognitive performance by treatment group at each follow-up

\begin{tabular}{|c|c|c|c|c|c|c|c|}
\hline \multirow[b]{3}{*}{ Time } & \multicolumn{4}{|c|}{ Treatment group } & \multicolumn{3}{|c|}{ Mixed model ${ }^{a}$ analysis with interactions } \\
\hline & \multicolumn{2}{|c|}{ Aspirin } & \multicolumn{2}{|c|}{ Placebo } & \multirow[b]{2}{*}{ Type } & \multirow[b]{2}{*}{ Coefficient } & \multirow[b]{2}{*}{$p$ Value } \\
\hline & No. & Mean (SD) & No. & Mean (SD) & & & \\
\hline \multicolumn{8}{|c|}{$\begin{array}{l}\text { Modified Mini-Mental State } \\
\text { Examination (3MS) }\end{array}$} \\
\hline Baseline & 9,525 & $93.4(4.7)$ & 9,589 & $93.5(4.6)$ & Time & -0.08 & $<0.001$ \\
\hline Year 1 & 8,895 & $94.2(4.8)$ & 8,974 & $94.2(4.7)$ & Group $\times$ time & -0.02 & 0.23 \\
\hline Year 3 & 7,344 & $93.9(5.4)$ & 7,385 & $93.9(5.3)$ & & & \\
\hline Year 4 & 851 & $93.9(6.2)$ & 877 & $93.9(5.4)$ & & & \\
\hline Year 5 & 3,456 & $93.5(6.5)$ & 3,528 & $93.5(6.4)$ & & & \\
\hline Year 6 & 820 & $94.0(7.1)$ & 834 & $94.1(6.3)$ & & & \\
\hline \multicolumn{8}{|c|}{$\begin{array}{l}\text { Hopkins Verbal Learning Test-Revised } \\
\text { (HVLT-R), Delayed Recall }\end{array}$} \\
\hline Baseline & 9,473 & $7.7(2.8)$ & 9,534 & $7.7(2.8)$ & Time & 0.01 & 0.01 \\
\hline Year 1 & 8,787 & $8.2(3.1)$ & 8,876 & $8.2(3.0)$ & Group $\times$ time & -0.004 & 0.58 \\
\hline Year 3 & 7,148 & $8.2(3.2)$ & 7,216 & $8.2(3.2)$ & & & \\
\hline Year 4 & 832 & $8.3(3.2)$ & 860 & $8.1(3.2)$ & & & \\
\hline Year 5 & 3,335 & $8.2(3.3)$ & 3,403 & $8.2(3.3)$ & & & \\
\hline Year 6 & 792 & $8.5(3.3)$ & 811 & $8.6(3.2)$ & & & \\
\hline \multicolumn{8}{|c|}{$\begin{array}{l}\text { Controlled Oral Word Association } \\
\text { Test (COWAT) (F) }\end{array}$} \\
\hline Baseline & 9,509 & $12.1(4.6)$ & 9,574 & $12.1(4.5)$ & Time & 0.23 & $<0.001$ \\
\hline Year 1 & 8,865 & $13.2(4.9)$ & 8,942 & $13.2(4.8)$ & Group $\times$ time & -0.003 & 0.80 \\
\hline Year 3 & 7,285 & $13.3(5.0)$ & 7,329 & $13.4(4.9)$ & & & \\
\hline Year 4 & 847 & $13.5(5.0)$ & 871 & $13.2(4.7)$ & & & \\
\hline Year 5 & 3,428 & $13.5(5.2)$ & 3,496 & $13.7(5.1)$ & & & \\
\hline Year 6 & 813 & $13.8(5.0)$ & 827 & $14.2(5.1)$ & & & \\
\hline \multicolumn{8}{|c|}{ Symbol Digit Modalities Test (SDMT) } \\
\hline Baseline & 9,491 & $36.7(10.1)$ & 9,539 & $36.8(10.2)$ & Time & -0.52 & $<0.001$ \\
\hline Year 1 & 8,818 & $36.8(10.1)$ & 8,883 & $37.0(10.1)$ & Group $\times$ time & -0.007 & 0.76 \\
\hline Year 3 & 7,219 & $35.8(10.2)$ & 7,237 & $35.9(10.1)$ & & & \\
\hline Year 4 & 839 & $35.8(10.5)$ & 865 & $35.7(10.2)$ & & & \\
\hline Year 5 & 3,363 & $34.9(10.1)$ & 3,424 & $35.1(10.2)$ & & & \\
\hline Year 6 & 803 & $35.8(10.2)$ & 813 & $35.7(10.7)$ & & & \\
\hline \multicolumn{8}{|c|}{ Composite cognitive score ${ }^{\mathrm{b}}$} \\
\hline Baseline & 9,442 & $-0.01(2.9)$ & 9,491 & $0.03(2.8)$ & Time & 0.01 & $<0.001$ \\
\hline Year 1 & 8,742 & $0.59(3.0)$ & 8,800 & $0.63(3.0)$ & Group $\times$ time & 0.001 & 0.89 \\
\hline Year 3 & 7,078 & $0.50(3.2)$ & 7,122 & $0.49(3.2)$ & & & \\
\hline Year 4 & 826 & $0.58(3.4)$ & 853 & $0.43(3.2)$ & & & \\
\hline Year 5 & 3,274 & $0.41(3.5)$ & 3,346 & $0.49(3.4)$ & & & \\
\hline Year 6 & 782 & $0.83(3.5)$ & 796 & $0.91(3.5)$ & & & \\
\hline
\end{tabular}

${ }^{a}$ A separate mixed-effects linear regression model for each cognitive test. These models contained the fixed effect of treatment group (aspirin vs placebo) at baseline (not shown above), which was not significant for any individual test, and time (annual visits) as main effects, and the 2-way interaction between treatment group and annual visit (which compared the mean change in cognitive function over time between groups).

${ }^{b}$ Composite cognition is a global composite cognitive score, an average of the cognitive tests 3MS, HVLT-R Delayed Recall, COWAT, and SDMT using $z$ Scores of each test. Scores for each test were standardized into $z$ scores based on mean and SD of the test at baseline. 
the median 4.7 years of follow-up was insufficient to see an effect of aspirin on dementia incidence and cognitive decline. Given the long prodromal phase of $\mathrm{AD}$ (the most common pathologic cause of dementia), participants diagnosed during the course of our study likely had significant dementia neuropathology when they enrolled. Prior studies have found that aspirin is ineffective in delaying progression of cognitive decline in individuals already diagnosed with dementia. ${ }^{38}$ Although we investigated the effect of aspirin on cognitive change in individuals without dementia or $\mathrm{MCI}$, there was only minor change in cognitive function in this sample over the median 4.7-year time frame. Finally, our results do not address the question of whether aspirin could be beneficial for preservation of cognitive function in middle-aged adults when neurodegenerative processes are likely to begin and the targeting of midlife vascular factors appears to be particularly crucial. ${ }^{39}$

ASPREE was the first prospectively planned placebocontrolled trial of aspirin therapy undertaken among individuals aged predominantly 70 years and over, among whom the risk of cognitive decline is greater and where an effective intervention could have the largest net benefit. This study provides no evidence that low-dose aspirin initiated in relatively healthy older adults is effective in preventing dementia, clinically probable $\mathrm{AD}$, or $\mathrm{MCI}$, or in reducing cognitive decline during active treatment over a median 4.7 years. This conclusion was consistent across a series of participant subgroups. The potential longer-term legacy effects of aspirin on these outcomes will be assessed with ongoing follow-up of the participants.

\section{Acknowledgment}

Bayer AG (Germany) provided the trial drug (aspirin) and placebo, but had no other role in the trial. The authors thank the staff in Australia and the United States for conducting the trial, the ASPREE participants, and the general practitioners and staff of the medical clinics who cared for the participants.

\section{Study funding}

The work was supported by the National Institute on Aging and the National Cancer Institute at the NIH (U01AG029824), the National Health and Medical Research Council (NHMRC) of Australia (334047 and 1127060), Monash University, and the Victorian Cancer Agency. J. Ryan is funded by an NHMRC Dementia Research Leader Fellowship (APP1135727). C. Reid is supported through an NHMRC Principal Research Fellowship (APP1136372).

\section{Disclosure}

A. Murray reports receiving consulting and travel fees from Bayer AG to present ASPREE primary results after their publication; consulting fees from Alkahest, Inc.; and grants from the National Institute on Aging. M. Nelson reports receiving consulting and travel fees from Bayer AG. R. Shah reports grants for clinical research regarding dementia and Alzheimer disease from NIH, the Centers for Medicare and
Medicaid Services, the Department of Defense, and the Illinois Department of Public Health; being a noncompensated board member of the Alzheimer's Association, Illinois Chapter; and being the site principal investigator or subinvestigator for clinical trials for which his institution (Rush University Medical Center) is compensated (Amylyx Pharmaceuticals, Inc.; Eli Lilly \& Co., Inc.; Genentech, Inc.; Merck \& Co, Inc.; Navidea Biopharmaceuticals; Novartis Pharmaceuticals, Inc.; Roche Holdings AG; and Takeda Development Center Americas, Inc.). Drs. J. Ryan, E. Storey, R. Woods, R. Wolfe, C. Reid, T. Chong, J. Williamson, S. Ward, J. Lockery, S. Orchard, R. Trevaks, B. Kirpach, A. Newman, M. Ernst, and J. McNeil report no disclosures relevant to the manuscript. Go to Neurology.org/ $\mathrm{N}$ for full disclosures.

\section{Publication history}

Received by Neurology September 2, 2019. Accepted in final form January 13, 2020.

\section{Appendix 1 Authors}

\begin{tabular}{|c|c|c|}
\hline Name & Location & Contribution \\
\hline $\begin{array}{l}\text { Trevor T.-J. } \\
\text { Chong, MBBS, } \\
\text { PhD }\end{array}$ & $\begin{array}{l}\text { Monash University, } \\
\text { Melbourne, Australia }\end{array}$ & $\begin{array}{l}\text { Data interpretation, } \\
\text { revised the manuscript } \\
\text { for intellectual content }\end{array}$ \\
\hline $\begin{array}{l}\text { Michael E. } \\
\text { Ernst, } \\
\text { PharmD }\end{array}$ & $\begin{array}{l}\text { The University of lowa, } \\
\text { lowa City }\end{array}$ & $\begin{array}{l}\text { Major role in acquisition } \\
\text { of data, revised the } \\
\text { manuscript for } \\
\text { intellectual content }\end{array}$ \\
\hline $\begin{array}{l}\text { Brenda } \\
\text { Kirpach, } \\
\text { CCRA }\end{array}$ & $\begin{array}{l}\text { Berman Center for Clinical } \\
\text { Outcomes and Research, } \\
\text { Hennepin Health Research } \\
\text { Institute, Minneapolis, MN }\end{array}$ & $\begin{array}{l}\text { Major role in acquisition } \\
\text { of data, revised the } \\
\text { manuscript for } \\
\text { intellectual content }\end{array}$ \\
\hline $\begin{array}{l}\text { Jessica } \\
\text { Lockery, } \\
\text { MBBS }\end{array}$ & $\begin{array}{l}\text { Monash University, } \\
\text { Melbourne, Australia }\end{array}$ & $\begin{array}{l}\text { Major role in the } \\
\text { acquisition of data, } \\
\text { revised the manuscript } \\
\text { for intellectual content }\end{array}$ \\
\hline $\begin{array}{l}\text { John McNeil, } \\
\text { MBBS, PhD }\end{array}$ & $\begin{array}{l}\text { Monash University, } \\
\text { Melbourne, Australia }\end{array}$ & $\begin{array}{l}\text { Designed and } \\
\text { conceptualized the } \\
\text { ASPREE study, revised } \\
\text { the manuscript for } \\
\text { intellectual content }\end{array}$ \\
\hline $\begin{array}{l}\text { Anne M. } \\
\text { Murray, MD, } \\
\text { MSc }\end{array}$ & $\begin{array}{l}\text { Hennepin Healthcare and } \\
\text { University of Minnesota, } \\
\text { Minneapolis }\end{array}$ & $\begin{array}{l}\text { Designed and } \\
\text { conceptualized the study, } \\
\text { interpreted the data, } \\
\text { revised the manuscript } \\
\text { for intellectual content }\end{array}$ \\
\hline $\begin{array}{l}\text { Mark Nelson, } \\
\text { MB, PhD }\end{array}$ & $\begin{array}{l}\text { Menzies Institute for } \\
\text { Medical Research, } \\
\text { University of Tasmania, } \\
\text { Hobart, Australia }\end{array}$ & $\begin{array}{l}\text { Designed and } \\
\text { conceptualized the } \\
\text { ASPREE study, revised } \\
\text { the manuscript for } \\
\text { intellectual content }\end{array}$ \\
\hline $\begin{array}{l}\text { Anne B. } \\
\text { Newman, } \\
\text { MD, MPH }\end{array}$ & University of Pittsburgh, PA & $\begin{array}{l}\text { Designed and } \\
\text { conceptualized the study, } \\
\text { revised the manuscript } \\
\text { for intellectual } \\
\text { content }\end{array}$ \\
\hline
\end{tabular}

Suzanne G. Monash University,

Orchard, PhD Melbourne, Australia

Major role in the acquisition of data, revised the manuscript for intellectual content 
Appendix 1 (continued)

\begin{tabular}{lll}
\hline Name & Location & Contribution \\
\hline Christopher & Curtin University, Perth; & $\begin{array}{l}\text { Designed and } \\
\text { M. Reid, PhD }\end{array}$ \\
& Monash University, & $\begin{array}{l}\text { ASPREE study, designed } \\
\text { Melbourne, Australia }\end{array}$ \\
& $\begin{array}{l}\text { process associated with } \\
\text { acquisition of data, } \\
\text { reviewed manuscript for } \\
\text { intellectual content }\end{array}$
\end{tabular}

\begin{tabular}{ll}
\hline Joanne Ryan, & Monash University, \\
PhD & Melbourne, Australia
\end{tabular}

intellectual content

Analyzed and interpreted the data, drafted the manuscript for intellectual content

Raj C. Shah, Rush University, Chicago, IL
MD
MD

\section{Designed and}

conceptualized the study, major role in the acquisition of data, interpreted the data, revised the manuscript for intellectual content

\begin{tabular}{ll}
\hline Elsdon & Monash University, \\
Storey, MBBS, & Melbourne, Australia \\
PhD &
\end{tabular}

Designed and

conceptualized the study,

taught and certified

Australian field staff, interpreted the data, revised the manuscript for intellectual content

\begin{tabular}{ll}
\hline Ruth Trevaks, & Monash University, \\
PhD & Melbourne, Australia
\end{tabular}

Major role in the acquisition of data, interpreted the data, revised the manuscript for intellectual content

\begin{tabular}{|c|c|c|}
\hline $\begin{array}{l}\text { Stephanie } \\
\text { Ward, BMed, } \\
\text { FRACP, MPH }\end{array}$ & $\begin{array}{l}\text { Monash University, } \\
\text { Melbourne, Australia }\end{array}$ & $\begin{array}{l}\text { Interpreted the data, } \\
\text { revised the manuscript } \\
\text { for intellectual content }\end{array}$ \\
\hline $\begin{array}{l}\text { Jeff } \\
\text { Williamson, } \\
\text { MD, MHS }\end{array}$ & $\begin{array}{l}\text { Wake Forest School of } \\
\text { Medicine, Winston-Salem, } \\
\text { NC }\end{array}$ & $\begin{array}{l}\text { Designed and } \\
\text { conceptualized the } \\
\text { ASPREE study, revised } \\
\text { the manuscript for } \\
\text { intellectual content }\end{array}$ \\
\hline $\begin{array}{l}\text { Robyn } \\
\text { Woods, PhD }\end{array}$ & $\begin{array}{l}\text { Monash University, } \\
\text { Melbourne, Australia }\end{array}$ & $\begin{array}{l}\text { Designed and } \\
\text { conceptualized the } \\
\text { ASPREE study, major role } \\
\text { in the acquisition of data, } \\
\text { revised the manuscript } \\
\text { for intellectual } \\
\text { content }\end{array}$ \\
\hline $\begin{array}{l}\text { Rory Wolfe, } \\
\text { PhD }\end{array}$ & $\begin{array}{l}\text { Monash University, } \\
\text { Melbourne, Australia }\end{array}$ & $\begin{array}{l}\text { Designed and } \\
\text { conceptualized the } \\
\text { ASPREE study, advised on } \\
\text { statistical analysis and } \\
\text { interpretation, revised } \\
\text { the manuscript for } \\
\text { intellectual content }\end{array}$ \\
\hline
\end{tabular}

\section{Appendix 2 Coinvestigators}

\begin{tabular}{llll}
\hline Name & Location & Role & Contribution \\
\hline $\begin{array}{l}\text { Walter } \\
\text { Abhayaratna }\end{array}$ & $\begin{array}{l}\text { Australian National } \\
\text { University }\end{array}$ & $\begin{array}{l}\text { International } \\
\text { steering } \\
\text { committee }\end{array}$ & Coinvestigator \\
\hline Lawrie Beilin & $\begin{array}{l}\text { University of Western } \\
\text { Australia }\end{array}$ & $\begin{array}{l}\text { International } \\
\text { steering } \\
\text { committee }\end{array}$ & Coinvestigator \\
& & & \\
& & &
\end{tabular}

\begin{tabular}{|c|c|c|c|}
\hline Name & Location & Role & Contribution \\
\hline $\begin{array}{l}\text { Andrew } \\
\text { Chan }\end{array}$ & $\begin{array}{l}\text { Massachusetts } \\
\text { General Hospital }\end{array}$ & $\begin{array}{l}\text { International } \\
\text { steering } \\
\text { committee }\end{array}$ & Coinvestigator \\
\hline $\begin{array}{l}\text { Jamehl } \\
\text { Demons }\end{array}$ & $\begin{array}{l}\text { Gerontology and } \\
\text { Geriatric Medicine, } \\
\text { Wake Forest Clinical } \\
\text { Trials Office }\end{array}$ & $\begin{array}{l}\text { International } \\
\text { steering } \\
\text { committee }\end{array}$ & Coinvestigator \\
\hline $\begin{array}{l}\text { Geoffrey } \\
\text { Donnan }\end{array}$ & $\begin{array}{l}\text { The Florey Institute of } \\
\text { Neuroscience and } \\
\text { Mental Health }\end{array}$ & $\begin{array}{l}\text { International } \\
\text { steering } \\
\text { committee }\end{array}$ & Coinvestigator \\
\hline $\begin{array}{l}\text { Sara } \\
\text { Espinoza }\end{array}$ & $\begin{array}{l}\text { UT Health Science } \\
\text { Center }\end{array}$ & $\begin{array}{l}\text { International } \\
\text { steering } \\
\text { committee }\end{array}$ & Coinvestigator \\
\hline $\begin{array}{l}\text { Matthew } \\
\text { Goetz }\end{array}$ & $\begin{array}{l}\text { Mayo Clinic Cancer } \\
\text { Center }\end{array}$ & $\begin{array}{l}\text { International } \\
\text { steering } \\
\text { committee }\end{array}$ & Coinvestigator \\
\hline $\begin{array}{l}\text { Colin } \\
\text { Johnston }\end{array}$ & Monash University & $\begin{array}{l}\text { International } \\
\text { steering } \\
\text { committee }\end{array}$ & Coinvestigator \\
\hline Danny Liew & Monash University & $\begin{array}{l}\text { International } \\
\text { steering } \\
\text { committee }\end{array}$ & Coinvestigator \\
\hline $\begin{array}{l}\text { Karen L. } \\
\text { Margolis }\end{array}$ & $\begin{array}{l}\text { HealthPartners } \\
\text { Institute for } \\
\text { Education \& } \\
\text { Research }\end{array}$ & $\begin{array}{l}\text { International } \\
\text { steering } \\
\text { committee }\end{array}$ & Coinvestigator \\
\hline $\begin{array}{l}\text { Frank } \\
\text { Meyskens }\end{array}$ & $\begin{array}{l}\text { Biological Chemistry, } \\
\text { School of Medicine, } \\
\text { UCI Chao Family } \\
\text { Comprehensive } \\
\text { Cancer Center }\end{array}$ & $\begin{array}{l}\text { International } \\
\text { steering } \\
\text { committee }\end{array}$ & Coinvestigator \\
\hline Nigel Stocks & $\begin{array}{l}\text { University of } \\
\text { Adelaide }\end{array}$ & $\begin{array}{l}\text { International } \\
\text { steering } \\
\text { committee }\end{array}$ & Coinvestigator \\
\hline $\begin{array}{l}\text { Andrew } \\
\text { Tonkin }\end{array}$ & Monash University & $\begin{array}{l}\text { International } \\
\text { steering } \\
\text { committee }\end{array}$ & Coinvestigator \\
\hline $\begin{array}{l}\text { John } \\
\text { Zalcberg }\end{array}$ & Monash University & $\begin{array}{l}\text { International } \\
\text { steering } \\
\text { committee }\end{array}$ & Coinvestigator \\
\hline
\end{tabular}

\section{References}

1. Piepoli MF, Hoes AW, Agewall S, et al. 2016 European guidelines on cardiovascular disease prevention in clinical practice: the sixth joint task force of the European Society of Cardiology and other societies on cardiovascular disease prevention in clinical practice (constituted by representatives of 10 societies and by invited experts) developed with the special contribution of the European Association for Cardiovascular Prevention \& Rehabilitation (EACPR). Atherosclerosis 2016;252:207-274.

2. Kinney JW, Bemiller SM, Murtishaw AS, Leisgang AM, Salazar AM, Lamb BT. Inflammation as a central mechanism in Alzheimer's disease. Alzheimers Dement 2018;4:575-590.

3. Chandra S, Jana M, Pahan K. Aspirin induces lysosomal biogenesis and attenuates amyloid plaque pathology in a mouse model of Alzheimer's disease via PPARalpha. J Neurosci 2018;38:6682-6699.

4. Hachinski V, Einhaupl K, Ganten D, et al. Preventing dementia by preventing stroke: the Berlin Manifesto. Alzheimers Dement 2019;15:961-984.

5. McGeer PL, Rogers J, McGeer EG. Inflammation, antiinflammatory agents, and Alzheimer's disease: the last 22 years. J Alzheimers Dis 2016;54:853-857.

6. Fink HA, Jutkowitz E, McCarten JR, et al. Pharmacologic interventions to prevent cognitive decline, mild cognitive impairment, and clinical Alzheimer-type dementia: a systematic review. Ann Intern Med 2018;168:39-51.

7. McNeil JJ, Woods RL, Nelson MR, et al. Effect of aspirin on disability-free survival in the healthy elderly. N Engl J Med 2018;379:1499-1508.

8. ASPREE IG. Study design of Aspirin in Reducing Events in the Elderly (ASPREE): a randomized, controlled trial. Contemp Clin Trials 2013;36:555-564. 
9. Lockery JE, Collyer TA, Abhayaratna WP, et al. Recruiting general practice patients for large clinical trials: lessons from the Aspirin in Reducing Events in the Elderly (ASPREE) study. Med J Aust 2019;210:168-173.

10. Teng EL, Chui HC. The Modified Mini-Mental State (3MS) examination. J Clin Psychiatry 1987;48:314-318

11. Ryan J, Woods RL, Britt C, et al. Normative performance of healthy older individuals on the Modified Mini-Mental State (3MS) examination according to ethno-racial group, gender, age, and education level. Clin Neuropsychol 2018;33:779-797.

12. Benedict RHB, Schretlen D, Groninger L, Brandt J. Hopkins Verbal Learning Test-Revised: normative data and analysis of inter-form and test-retest reliability. Clin Neuropsychol 2001;12:43-55.

13. Ross TP. The reliability of cluster and switch scores for the Controlled Oral Word Association Test. Arch Clin Neuropsychol 2003;18:153-164.

14. Smith A. Symbol Digit Modalities Test (SDMT) Manual (Revised). Los Angeles: Western Psychological Services; 1982.

15. Bland RC, Newman SC. Mild dementia or cognitive impairment: the Modified MiniMental State Examination (3MS) as a screen for dementia. Can J Psychiatry 2001;46: 506-510.

16. Tombaugh TN. Test-retest reliable coefficients and 5-year change scores for the MMSE and 3MS. Arch Clin Neuropsychol 2005;20:485-503.

17. Graham DP, Cully JA, Snow AL, Massman P, Doody R. The Alzheimer's Disease Assessment Scale-Cognitive Subscale: normative data for older adult controls. Alzheimer Dis Assoc Disord 2004;18:236-240.

18. D’Elia L. Color Trails Test: Professional Manual. Odessa, FL: Psychological Assessment Resources; 1996.

19. Alegret M, Boada-Rovira M, Vinyes-Junque G, et al. Detection of visuoperceptual deficits in preclinical and mild Alzheimer's disease. J Clin Exp Neuropsychol 2009;31:860-867.

20. J. F. Alzheimer's Disease. Cooperative Study ADL Scale. In: Encyclopedia of Clinical Neuropsychology. New York: Springer; 2011.

21. American Psychiatric Association. Diagnostic and Statistical Manual of Mental Disorders (DSM-IV). Washington, DC: American Psychiatric Association; 1994.

22. McKhann GM, Knopman DS, Chertkow H, et al. The diagnosis of dementia due to Alzheimer's disease: recommendations from the National Institute on AgingAlzheimer's Association workgroups on diagnostic guidelines for Alzheimer's disease. Alzheimers Dement 2011;7:263-269.

23. Albert MS, DeKosky ST, Dickson D, et al. The diagnosis of mild cognitive impairment due to Alzheimer's disease: recommendations from the National Institute on Aging-Alzheimer's Association workgroups on diagnostic guidelines for Alzheimer's disease. Alzheimers Dement 2011;7:270-279.
24. Wolfe R, Murray AM, Woods RL, et al. The Aspirin in Reducing Events in the Elderly Trial: statistical analysis plan. Int J Stroke 2018;13:335-338.

25. Andersen PK, Geskus RB, de Witte T, Putter H. Competing risks in epidemiology: possibilities and pitfalls. Int J Epidemiol 2012;41:861-870.

26. Jutten RJ, Harrison JE, Lee Meeuw Kjoe PR, et al. Assessing cognition and daily function in early dementia using the cognitive-functional composite: findings from the Catch-Cog study cohort. Alzheimers Res Ther 2019;11:45.

27. Naka H, Nomura E, Kitamura J, Imamura E, Wakabayashi S, Matsumoto M. Antiplatelet therapy as a risk factor for microbleeds in intracerebral hemorrhage patients: analysis using specific antiplatelet agents. J Stroke Cerebrovasc Dis 2013;22:834-840.

28. Martinez-Ramirez S, Greenberg SM, Viswanathan A. Cerebral microbleeds: overview and implications in cognitive impairment. Alzheimers Res Ther 2014;6:33.

29. Zhang C, Wang Y, Wang D, Zhang J, Zhang F. NSAID exposure and risk of Alzheimer's disease: an updated meta-analysis from cohort studies. Front Aging Neurosci $2018 ; 10: 83$.

30. de Craen AJ, Gussekloo J, Vrijsen B, Westendorp RG. Meta-analysis of nonsteroidal antiinflammatory drug use and risk of dementia. Am J Epidemiol 2005;161:114-120.

31. Kang JH, Cook N, Manson J, Buring JE, Grodstein F. Low dose aspirin and cognitive function in the Women's Health Study cognitive cohort. BMJ 2007;334:987.

32. Price JF, Stewart MC, Deary IJ, et al. Low dose aspirin and cognitive function in middle aged to elderly adults: randomised controlled trial. BMJ 2008;337:a1198.

33. Gargiulo G, Capodanno D, Longo G, Capranzano P, Tamburino C. Updates on NSAIDs in patients with and without coronary artery disease: pitfalls, interactions and cardiovascular outcomes. Expert Rev Cardiovasc Ther 2014;12:1185-1203.

34. ADAPT. Results of a follow-up study to the randomized Alzheimer's Disease AntiInflammatory Prevention Trial (ADAPT). Alzheimers Dement 2013;9:714-723.

35. Meyer PF, Tremblay-Mercier J, Leoutsakos J, et al. INTREPAD: a randomized trial of naproxen to slow progress of presymptomatic Alzheimer disease. Neurology 2019;92: e2070-e2080.

36. Mehta KM, Yeo GW. Systematic review of dementia prevalence and incidence in United States race/ethnic populations. Alzheimers Dement 2017;13:72-83.

37. Roberts RO, Geda YE, Knopman DS, et al. The incidence of MCI differs by subtype and is higher in men: the Mayo Clinic Study of Aging. Neurology 2012;78:342-351.

38. Bentham P, Gray R, Sellwood E, Hills R, Crome P, Raftery J. Aspirin in Alzheimer's disease (AD2000): a randomised open-label trial. Lancet Neurol 2008;7:41-49.

39. Knopman DS, Gottesman RF, Sharrett AR, et al. Midlife vascular risk factors and midlife cognitive status in relation to prevalence of mild cognitive impairment and dementia in later life: the Atherosclerosis Risk in Communities Study. Alzheimers Dement 2018;14:1406-1415. 


\section{Neurology}

\section{Randomized placebo-controlled trial of the effects of aspirin on dementia and cognitive decline}

Joanne Ryan, Elsdon Storey, Anne M. Murray, et al.

Neurology 2020;95;e320-e331 Published Online before print March 25, 2020

DOI 10.1212/WNL.0000000000009277

\section{This information is current as of March 25, 2020}

\section{Updated Information \&} Services

References

Citations

Subspecialty Collections

Permissions \& Licensing

Reprints including high resolution figures, can be found at: http://n.neurology.org/content/95/3/e320.full

This article cites 35 articles, 5 of which you can access for free at: http://n.neurology.org/content/95/3/e320.full\#ref-list-1

This article has been cited by 3 HighWire-hosted articles: http://n.neurology.org/content/95/3/e320.full\#\#otherarticles

This article, along with others on similar topics, appears in the following collection(s):

All CBMRT/Null Hypothesis

http://n.neurology.org/cgi/collection/all_cbmrt_null_hypothesis

Alzheimer's disease

http://n.neurology.org/cgi/collection/alzheimers_disease

Clinical trials Randomized controlled (CONSORT agreement)

http://n.neurology.org/cgi/collection/clinical_trials_randomized_contro lled_consort_agreement

MCI (mild cognitive impairment)

http://n.neurology.org/cgi/collection/mci_mild_cognitive_impairment

Information about reproducing this article in parts (figures,tables) or in its entirety can be found online at:

http://www.neurology.org/about/about_the_journal\#permissions

Information about ordering reprints can be found online:

http://n.neurology.org/subscribers/advertise

Neurology ${ }^{\circledR}$ is the official journal of the American Academy of Neurology. Published continuously since 1951, it is now a weekly with 48 issues per year. Copyright () 2020 American Academy of Neurology. All rights reserved. Print ISSN: 0028-3878. Online ISSN: 1526-632X.

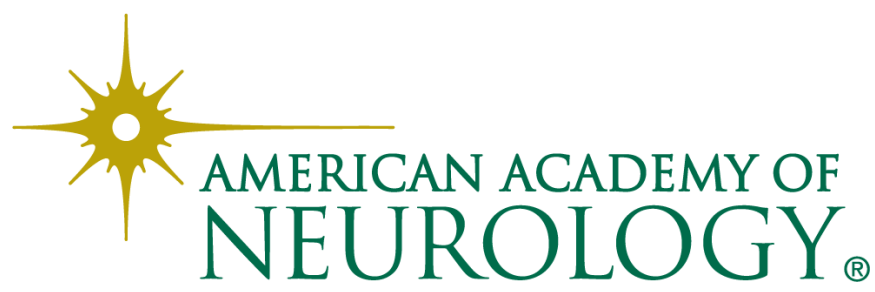

